\title{
Refractory giant cell arteritis: the value of clinical symptoms and imaging
}

\author{
Alexander Pfeil, ${ }^{1}$ Marcus Franz, ${ }^{2}$ Gunter Wolf, ${ }^{1}$ Martin Freesmeyer ${ }^{3}$
}

'Department of Internal Medicine III, University Hospital Jena, Jena, Germany ${ }^{2}$ Department of Internal Medicine I, University Hospital Jena, Jena, Thueruingen, Germany

${ }^{3}$ Clinic of Nuclear Medicine, University Hospital Jena, Jena, Germany

\section{Correspondence to}

Prof. Dr Marcus Franz; marcus.Franz@med.uni-jena.de

Accepted 14 July 2020

\section{DESCRIPTION}

Tocilizumab is a new option in the treatment of giant cell arteritis. ${ }^{1}$ Based on normal acute phase reactants in the treatment of giant cell arteritis with tocilizumab, the detection of disease flare may be difficult.

A 72-year-old woman was admitted to hospital with pain and stiffness of the shoulder girdle as well as occipital headache. The C-reactive protein (CRP) was $20.2 \mathrm{mg} / \mathrm{L}$ (reference: $<2.0 \mathrm{mg} / \mathrm{L}$ ). The power Doppler ultrasound showed a halo phenomenon of both common carotid arteries. The diagnosis based on the clinical, laboratory findings and ultrasound was giant cell arteritis. According to the clinical standard, a prednisolone therapy with $60 \mathrm{mg} /$ day was initiated. ${ }^{2}$ All symptoms disappeared. After tapering prednisone to $40 \mathrm{mg}$ per day, the patient presented a new onset of pain and stiffness in the shoulder girdle with occipital headache with a normal CRP. A (18)F-fluorodeoxyglucose positron emission tomography-CT (PET-CT) was performed for further evaluation and revealed inflammatory activity of the aorta, supraaortal arteries (see figure 1A) and the arteries of the upper and lower extremity. Consequently, the

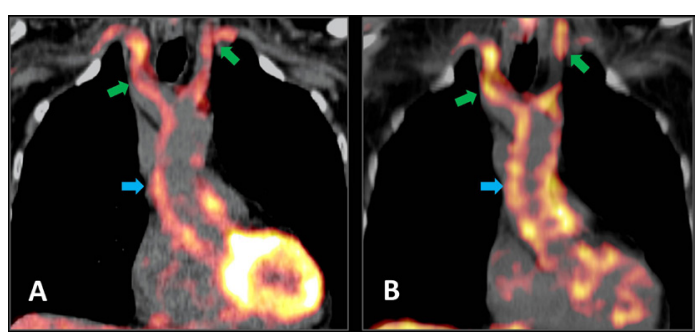

Check for updates

(C) BMJ Publishing Group Limited 2020. No commercial re-use. See rights and permissions. Published by BMJ.

To cite: Pfeil A, Franz M, Wolf $\mathrm{G}$, et al. BMJ Case Rep 2020;13:e237623. doi:10.1136/bcr-2020237623
Figure 1 (A) (18)F-fluorodeoxyglucose positron emission tomography-CT (PET-CT) presented inflammatory activity of the aortic wall (blue arrow) and supraaortal arteries (green arrows) indicating a giant cell arteritis resulting in the initiation of an tocilizumab therapy and (B) the (18)F-fluorodeoxyglucose uptake of the aorta and supraaortal arteries in PET-CT in association with anew pain, stiffness in the shoulder girdle and occipital headache under the therapy with tocilizumab revealed a flare of giant cell arteritis.

\section{Learning points}

- Clinical symptoms, in combination with imaging, are markers for the detection of giant cell arteritis flare.

- CRP is not a marker for the dection of a disease flare.

prednisone dose was increased to $60 \mathrm{mg} /$ day and a therapy with tocilizumab was introduced. Prednisone was tapered in 26-week schema based on the GiACTA Trial. ${ }^{1}$ Two months later, the patient revealed anew pain and stiffness in the shoulder girdle associated with occipital headache. The CRP value was normal and the PET-CT showed again typical signs of giant cell arteritis (see figure 1B).

The case report describes a flare of giant cell arteritis, which was detectable by clinical symptoms and PET-CT imaging. In this context, CRP is no indicator for the detection of flare in the treatment with prednisone plus tocilizumab. ${ }^{3}$ The assessment of clinical symptoms in combination with imaging (eg, PET-CT) seems to be potential markers for the detection of a disease flare. Further studies were required to verify this finding.

Contributors AP, MFranz, GW and MFreesmeyer treated the patient, collected and interpreted the data and wrote the manuscript.

Funding The authors have not declared a specific grant for this research from any funding agency in the public, commercial or not-for-profit sectors.

Competing interests None declared.

Patient consent for publication Obtained.

Provenance and peer review Not commissioned; externally peer reviewed.

\section{REFERENCES}

1 Stone JH, Tuckwell K, Dimonaco S, et al. Trial of tocilizumab in giantcell arteritis. N Engl J Med Overseas Ed 2017;377:317-28.

2 Pfeil A, Oelzner P, Hellmann P. The treatment of giant cell arteritis in different clinical settings. Front Immunol 2018;9:3129.

3 Stone JH, Tuckwell K, Dimonaco S, et al. Glucocorticoid dosages and acute-phase reactant levels at giant cell arteritis flare in a randomized trial of tocilizumab. Arthritis Rheumatol 2019;71:1329-38 
Copyright 2020 BMJ Publishing Group. All rights reserved. For permission to reuse any of this content visit https://www.bmj.com/company/products-services/rights-and-licensing/permissions/

BMJ Case Report Fellows may re-use this article for personal use and teaching without any further permission.

Become a Fellow of BMJ Case Reports today and you can:

- Submit as many cases as you like

Enjoy fast sympathetic peer review and rapid publication of accepted articles

Access all the published articles

Re-use any of the published material for personal use and teaching without further permission

Customer Service

If you have any further queries about your subscription, please contact our customer services team on +44 (0) 2071111105 or via email at support@bmj.com.

Visit casereports.bmj.com for more articles like this and to become a Fellow 